\title{
GEM/POPs: a global 3-D dynamic model for semi-volatile persistent organic pollutants - Part 2: Global transports and budgets of PCBs
}

\author{
P. Huang ${ }^{1}$, S. L. Gong ${ }^{1,2}$, T. L. Zhao ${ }^{2}$, L. Neary ${ }^{3}$, and L. A. Barrie ${ }^{4}$ \\ ${ }^{1}$ Air Quality Research Division, Science \& Technology Branch, Environment Canada, 4905 Dufferin Street, Toronto, Ontario \\ M3H 5T4, Canada \\ ${ }^{2}$ Dept. of Chemical Engineering and Applied Chemistry, University of Toronto, 200 College Street, Toronto, Ontario, \\ Canada, M5S 3E5, Canada \\ ${ }^{3}$ Dept. of Earth and Space Science and Engineering, York University, 4700 Keele Street, Toronto, Ontario, M3J 1P3, Canada \\ ${ }^{4}$ Atmospheric Research and Environment Program, World Meteorological Organization, 7 bis, avenue de la Paix, BP2300, \\ 1211 Geneva 2, Switzerland
}

Received: 19 January 2007 - Published in Atmos. Chem. Phys. Discuss.: 16 March 2007

Revised: 2 July 2007 - Accepted: 24 July 2007 - Published: 1 August 2007

\begin{abstract}
Global transports and budgets of three PCBs were investigated with a 3-D dynamic model for semi-volatile persistent organic pollutants - GEM/POPs. Dominant pathways were identified for PCB transports in the atmosphere with a transport flux peaking below $8 \mathrm{~km}$ for gaseous and $14 \mathrm{~km}$ for particulate PCB28, and peaking below $4 \mathrm{~km}$ for gaseous and $6 \mathrm{~km}$ for particulate PCB180. The inter-continental transports of PCBs in the Northern Hemisphere $(\mathrm{NH})$ are dominated in the zonal direction with their route changes regulated seasonally by the variation of westerly jet. The transport pathways from Europe and North Atlantic contributed the most PCBs to the Arctic. Inter-hemispheric transports of PCBs originated from the regions of Europe, Asia and North America in three different flow-paths, accompanying with easterly jet, Asian monsoon winds and trade winds. PCBs from the Southern Hemisphere (SH) could also be exported into the NH. According to the PCB emissions of year 2000, Europe, North America and Asia are the three largest sources of the three PCBs, contributing to the global background concentrations in the atmosphere, soil and water. Globally, PCB28 in soil and water has become a comparable source to the anthropogenic emissions while heavier PCBs such as PCB153 and 180 are still transporting into soil and water. For all three congeners, particulate PCBs are concentrated in the higher levels than gaseous PCBs. More than half of the particulate PCB28 could reach up to the stratosphere, while most of the heavier counter-parts (PCB153 and PCB180) are stored in the troposphere including boundary layer with more than $99 \%$ gaseous PCB180 below $6 \mathrm{~km}$.
\end{abstract}

Correspondence to: S. Gong

(sunling.gong@ec.gc.ca)

\section{Introduction}

There is a growing international concern with identifying and managing environmentally persistent substances that are both transported to and deposited into the biosphere of regions far from the place where they were used and released. Atmospheric transport is believed to be the primary mode for conveying persistent substances to these remote regions (Wania, 2003). POPs vary greatly in properties such as vapour pressure, solubility in water, and reactivity, thus their transport and deposition in the environment depends on the unique combination of persistence and partitioning, which differ considerably from chemical to chemical. These differences in properties translate into differences in chemical fate of various POPs (Mackay et al., 2006).

Previous researches on long range transport (LRT) and deposition of POPs have been mostly limited in assessing the potential for LRT and using simple multimedia models for substances such as the hexachlorocyclohexanes (Wania et al., 1999) and PCBs (Hung et al., 2005b; MacLeod et al., 2005; Wania and Daly, 2002; Wania and Su, 2004). These models have been used in demonstrating the "grasshopper" effect and in examining movement of POPs over the globe on time scales of several decades in a steady state mode to investigate the partitioning behavior of POPs or in a dynamic mode to simulate the environmental fate of a compound. Due to the limited spatial and temporal resolutions of these models, a source-receptor relationship can hardly be inferred quantitatively for any specific geographical regions. Consequently, dynamical 3-D models have been developed to describe the atmospheric transport of POPs on both regional (Ma et al.,

Published by Copernicus Publications on behalf of the European Geosciences Union. 
2003; van Jaarsveld et al., 1997), hemispheric (Hansen et al., 2005; Malanichev et al., 2004) and global scales (Gong et al., 2007; Koziol and Pudykiewicz, 2001; Semeena and Lammel, 2005; Strand and Hov, 1996). Transport and deposition patterns of various POPs have been investigated with respect to factors such as the climate fluctuations. One thing that lacks in these 3-D model studies was the investigation of the budgets and deposition patterns of inter-continental transports of various semi-volatile POPs. The quantitative relationship between the emissions in one region and the environmental levels in another region hundreds and thousands of kilometers away was not properly addressed under various partitioning conditions.

As described in a previous paper (Gong et al., 2007), a 3D global POPs transport model with a dynamic aerosol module (GEM/POPs) has been developed to simulate the transport, deposition and partitioning of semi-volatile POPs in the atmosphere. Comparisons of GEM/POPs results with observations have revealed that the GEM/POPs can reasonably simulate the atmospheric distributions of three typical PCBs from volatile (PCB28) to semi-volatile (PCB153 and PCB180) species for their ranges and seasonal variations of the atmospheric concentrations, which allows the further investigation of PCB global transport patterns and budgets. This paper is devoted to present the current status of atmospheric PCBs in terms of their reservoirs, inter-continental transports and deposition patterns in an effort to comprehensively understand the nature of PCBs.

\section{GEM/POPs essentials}

Full details of the development of GEM/POPs by a Canadian community effort are given in a previous paper (Gong et al., 2007). This section briefly reviews the key components of the modelling system. Four major functional blocks constitute the GEM/POPs system: transport, exchange/emission, particulate and gaseous processes. The transport of POPs is carried out atmospherically by the Global Environmental Multiscale (GEM) model (Côté et al., 1998) developed at MSC (Meteorological Service of Canada) for weather forecasting applications and oceanically by prescribed ocean currents and a ocean tracer transport module. The exchanges of POPs between atmosphere and water/soil as well as the anthropogenic emission provide GEM/POPs the net fluxes into the atmosphere where they are engaged into transport, gaseous and particulate processes. Within the particulate processes, an on-line aerosol module CAM (Canadian Aerosol Module) (Gong et al., 2003) computes dynamically the aerosol surface areas from five major aerosol components: sea-salt, sulphate, black carbon, organic carbon and soil dust. The dry and wet removals of particle-bound PCBs are also treated in this block, the downward fluxes of which are added to the soil and water reservoirs, respectively. Finally, the degradation by $\mathrm{OH}$, gas-particle partition as well as the dry and wet removals of gaseous PCBs is handled in the gaseous phase block. The deposition fluxes of gaseous phase PCBs are dynamically tracked in soil and water reservoirs as well.

\section{Global transports of PCBs}

The global transports of PCBs are investigated based on the analyses of transport flux which is calculated in zonal and meridional components by multiplying PCB-concentration and zonal/meridional wind velocity components. Therefore positive (negative) transport flux components of PCBs indicate eastward (westward) transport in zonal direction or northward (southward) transport in meridional direction depending on the directions of wind velocity components. As a vector variable, transport flux is used to estimate the amount and direction of PCB transport in this section.

\subsection{Global Transport Patterns}

Figure 1 shows the meridional cross-section of zonal and meridional components of globally mean PCB-transport fluxes averaged over the year 2000. Climatologically, west winds prevail with the westerly jets in the mid-latitudes of both NH and SH for all seasons. Therefore, it could be expected that the zonal transports of both volatile (e.g. PCB28) and semi-volatile (e.g. PCB180) PCBs in the eastward direction over the mid-latitudes of both hemispheres are globally the strongest considering the major PCB-sources there, although the minor westward transports of PCBs occurred in the easterlies over the low- and high-latitudes. It can also be seen that most PCBs were transported in the troposphere. In the $\mathrm{NH}$, the zonal PCB-transports peaked below $4 \mathrm{~km}$ for the gaseous PCB180, $6 \mathrm{~km}$ for the particulate PCB180, $8 \mathrm{~km}$ for the gaseous PCB28 and $14 \mathrm{~km}$ for particulate PCB28 with the transport centers around $50^{\circ} \mathrm{N}$. In the $\mathrm{SH}$, the eastward transports centered around $40^{\circ} \mathrm{S}$ and peaked at the higher altitudes with a lower strength than in the $\mathrm{NH}$, primarily due to long range transport from the source regions in the $\mathrm{NH}$ (Figs. 1a-d). The lighter PCB (i.e. PCB28) is transported with stronger westerlies at higher layers than the heavier PCB (i.e. PCB180), which implied that the lighter PCB exhibits a higher LRT-potential than the heavier PCB. The globally averaged transport flux components in the meridional direction indicated that PCBs from the regions at the latitudinal range $40-50^{\circ} \mathrm{N}$ could transport northwards into the arctic region and southwards into the low-latitudes, and cross equator into the SH (Figs. 1e-h). The meridional transports of PCBs were also mostly limited in the troposphere at the same altitudes with the zonal transports except for the particulate PCB28. Compared to the semi-volatile PCB180, more particulate PCB28 could be volatized into the gas phase proportionally to the air temperature. Therefore, the pattern of meridional transports for the particulate PCB28 was formed 

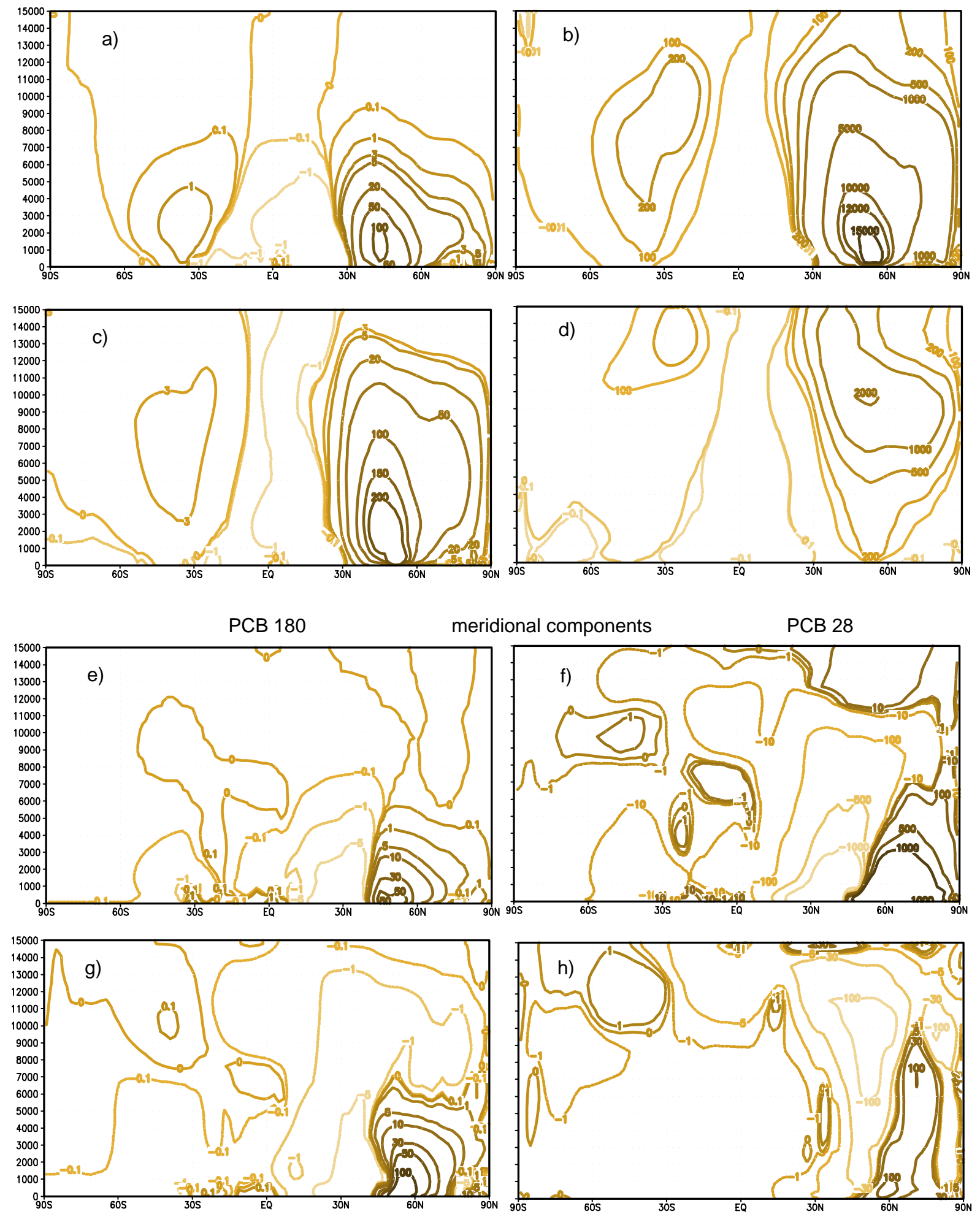

Fig. 1. The meridional cross-section of globally mean PCB-transport fluxes $\left(\mathrm{ng} \mathrm{km}^{-2} \mathrm{~s}^{-1}\right)$ averaged over the year 2000 with the zonal components of (a) gaseous PCB180, (b) gaseous PCB28, (c) particulate PCB180, (d) particulate PCB28 and the meridional components of (e) gaseous PCB180, (f) gaseous PCB28, (g) particulate PCB180 and (h) particulate PCB28. The vertical coordinates are for the altitude (m) from surface. 
PCB28

Winter
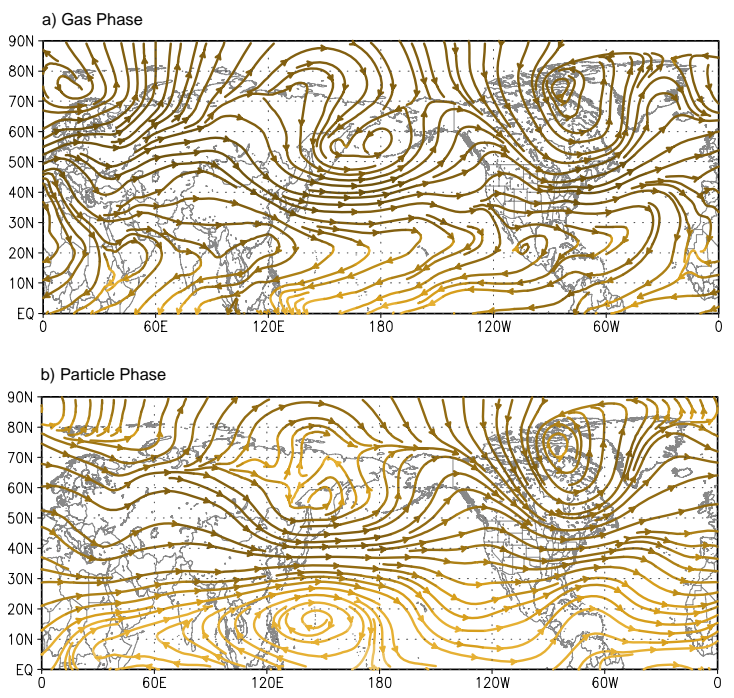

Summer
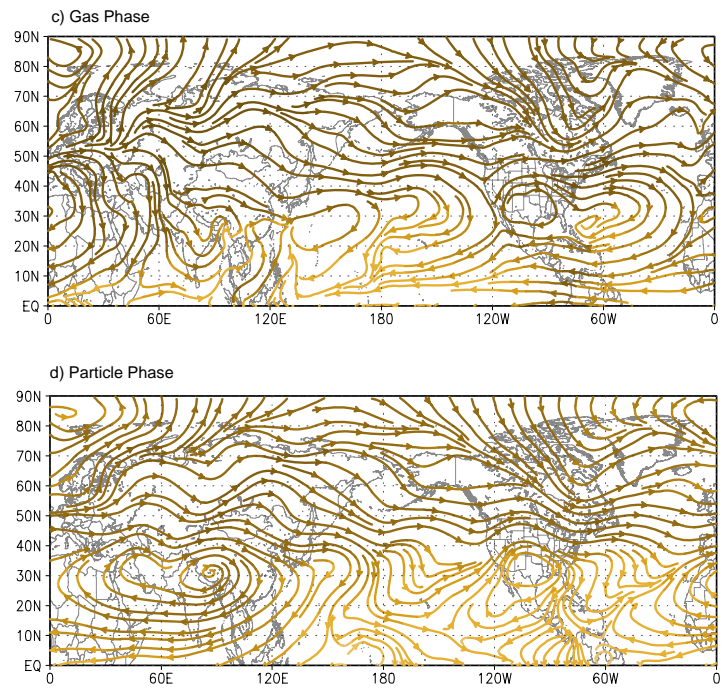

\section{PCB180}
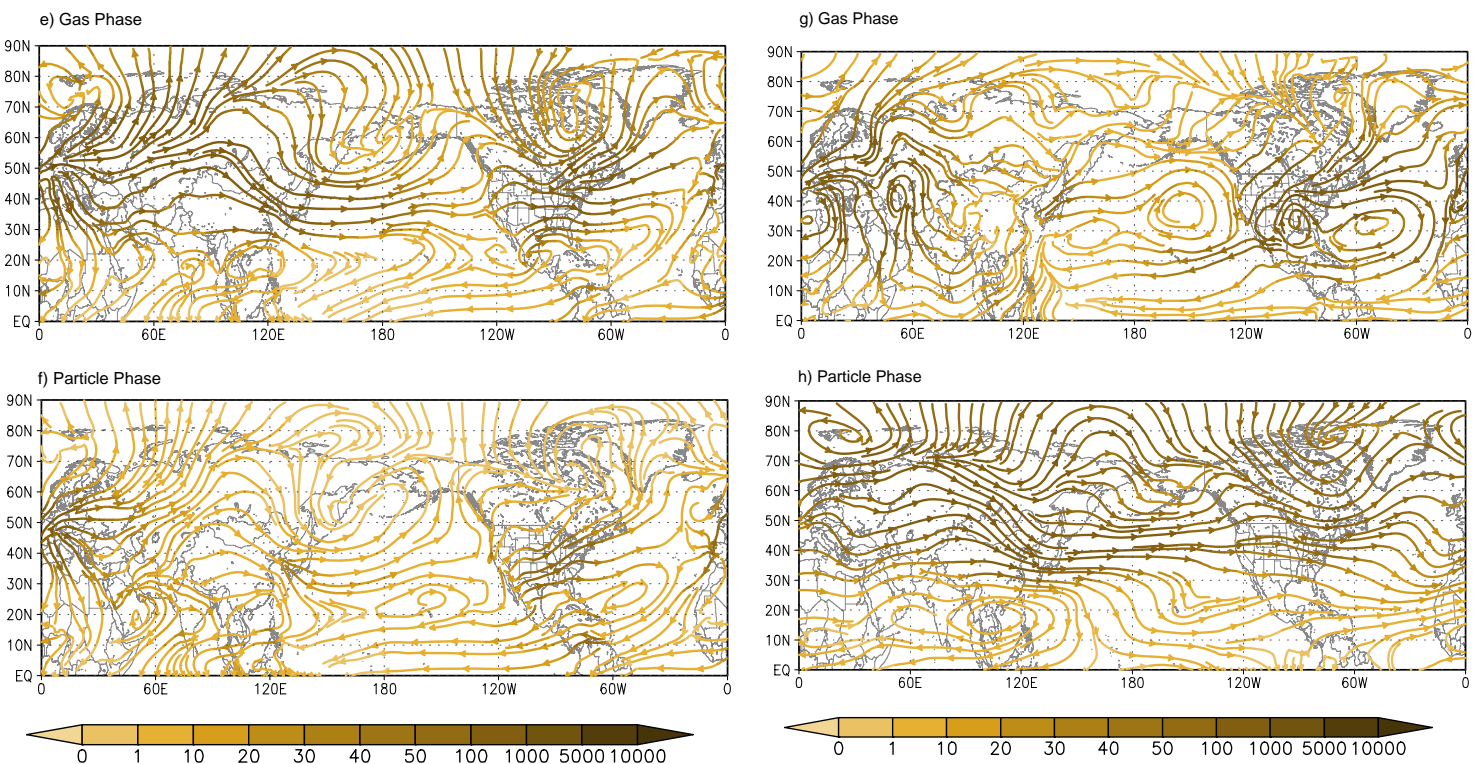

Fig. 2. Seasonally mean streamlines of PCB28-transport fluxes $\left(\times 20 \mathrm{ng} \mathrm{km}^{-2} \mathrm{~s}^{-1}\right)$ averaged below the limited vertical layers in winter for (a) gas and (b) particles, and in summer for (c) gas and (d) particles. The limited vertical layers are at $8 \mathrm{~km}$ for gaseous PCB28 and $14 \mathrm{~km}$ for particulate PCB28. Seasonally mean streamlines of PCB180-transport fluxes (ng km ${ }^{-2} \mathrm{~s}^{-1}$ ) averaged below the limited vertical layers in winter (e) for gas and (f) for particles and in summer (g) for gas and (h) for particles. The limited vertical layers are at $4 \mathrm{~km}$ for gaseous PCB 180 and $6 \mathrm{~km}$ for particulate PCB180.

with the major transport layers descending from the warm low-latitudes to the cold high-latitudes in both hemispheres. In the $\mathrm{NH}$, the most PCB28-particles transported northwards from mid- to high-latitudes below $8 \mathrm{~km}$, southwards from mid- to low-latitudes between $6 \mathrm{~km}$ and $12 \mathrm{~km}$, and across the equator at the altitudes of $10 \mathrm{~km}-14 \mathrm{~km}$ (Fig. 1h). It is also found in Fig. 1 that more gaseous PCB28 than particulate PCB28 were involved in LRT in both zonal and meridional directions, while more particulate PCB180 than gaseous PCB180 were engaged in LRT. These differences in the PCB transport amounts and layers of lighter PCB28 and heavier PCB180 are related with their magnitude of 
Table 1. Emissions of Selected PCB Congeners from Different Regions in Year 2000 (kg).

\begin{tabular}{llccccccccc}
\hline & Media & Europe & Asia & Pacific & $\begin{array}{c}\text { North } \\
\text { America }\end{array}$ & Atlantic & Arctic & SH & $\begin{array}{c}\text { Low } \\
\text { Latitude }\end{array}$ & Total \\
\hline \multirow{2}{*}{ PCB28 } & Anthropogenic & 33644.40 & 7269.09 & 210.47 & 9260.15 & 92.28 & 259.92 & 1985.06 & 1942.38 & 54663.75 \\
& Soil & 24281.40 & 9232.98 & 68.83 & 6170.20 & 32.48 & 1587.36 & -612.17 & -135.80 & 40625.28 \\
& Water & 481.49 & 25.21 & 307.93 & 18.73 & 498.94 & -920.33 & -128.87 & -59.96 & 223.14 \\
& Anthropogenic & 7974.51 & 1178.72 & 36.19 & 1488.72 & 37.83 & 37.28 & 683.97 & 662.75 & 12099.96 \\
PCB153 & Soil & -4252.65 & -802.00 & -25.24 & -528.09 & -7.81 & -45.60 & -484.97 & -334.57 & -6480.93 \\
& Water & -232.87 & -24.98 & -18.93 & -45.86 & -42.83 & -5.47 & -34.32 & -29.74 & -435.00 \\
& Anthropogenic & 1974.27 & 251.83 & 9.76 & 481.84 & 10.57 & 7.14 & 187.50 & 181.08 & 3104.01 \\
PCB180 & Soil & -723.66 & -132.76 & -2.81 & 236.98 & 1.90 & 5.46 & -144.88 & -111.40 & -871.17 \\
& Water & -46.03 & -4.69 & -4.78 & -14.98 & -13.78 & -1.02 & -6.95 & -12.48 & -104.71 \\
\hline
\end{tabular}

emission, chemical degradation, deposition (Table 2) and the gaseous and particulate processes (Gong et al., 2007).

\subsection{Inter-continental transports in $\mathrm{NH}$}

Based on the above analysis of the PCB transport layers, the transport fluxes averaged from surface to $8 \mathrm{~km}$ for gaseous PCB28, to $14 \mathrm{~km}$ for the particulate PCB28, to $4 \mathrm{~km}$ for the gaseous PCB180 and to $6 \mathrm{~km}$ for the particulate PCB180 were used to further describe the global transport patterns and their seasonal variations with the streamline fields in Fig. 2 to more comprehensively understand the global transports.

Closely associated with the atmospheric general circulation especially with westerly wave in the mid-latitudes, the inter-continental transports of PCBs in the $\mathrm{NH}$ are dominant in the eastward direction along the westerlies (Fig. 2). The inter-continental transport routes changed from the more meridional structures in winter and spring to the more zonal structures in summer and autumn, associated with the seasonal evolution of trough and ridge system in westerly wave. In winter the meridional transport pattern was well built up with three ridges over the regions: 1) from central Asia to Siberia, 2) between Eastern Pacific and western North America and 3) of western Atlantic and with two troughs: 1) from East Asia to western Pacific and 2) over eastern North America (Figs. 2a-b, 2e-f). The strongest ridge from central Asia to Siberia brought PCBs from Europe across the high latitudes and the arctic into East Asia, North Pacific and even North America. The PCB sources in Europe seem to be the most important for the inter-continental transports in the $\mathrm{NH}$. The stream jets of PCB-transports in the two trough regions carried PCBs from Eurasian continent to Pacific and from North America to Atlantic Ocean (Figs. 2a-b, 2e-f). The seasonal variations of stream jets are featured with their centre location at $35^{\circ} \mathrm{N}$ in winter (Figs. $2 \mathrm{a}-\mathrm{b}, 2 \mathrm{e}-\mathrm{f}$ ), $40-45^{\circ} \mathrm{N}$ in spring/autumn and $50^{\circ} \mathrm{N}$ in summer (Figs. $2 \mathrm{c}-\mathrm{d}, 2 \mathrm{~g}-2 \mathrm{~h}$ ). In summer the zonal PCB-transport pattern was most clearly developed with the weakest trough and ridge system in the westerlies of the $\mathrm{NH}$, especially for PCB28 in the middle and upper troposphere (Figs. 2c-d). For the heavier PCB180transports in the lower troposphere with the stronger effects from the topography, the inter-continental transport routes with the less zonal and less streamline structures could also present a lower potential for LRT (Figs. 2e-h).

Figures $3 \mathrm{a}$ and $4 \mathrm{a}$ further quantify the transport mass of PCB28 and PCB180 up to $35 \mathrm{~km}$ in year 2000 . To facilitate the discussions, the globe is divided into 8 regions, representing the Europe, Asia, North Pacific, North America, Atlantic, Arctic, SH and NH low-latitude, respectively as shown in Figs. 3 and 4. For European region, the sum of imported gaseous and particulate PCBs was $4358 \mathrm{~kg}$ and $71 \mathrm{~kg}$ for PCB28 (Fig. 3a) and PCB180 (Fig. 4a), respectively, while those two congeners exported from the European region totalled $26491 \mathrm{~kg}$ and $297 \mathrm{~kg}$, which confirmed that Europe was the largest PCB-sources for LRT. From Europe, $20276 \mathrm{~kg}$ of total exported PCB28 and $192 \mathrm{~kg}$ of total exported PCB180 transferred eastwards to Asian region, $5914 \mathrm{~kg}$ of PCB2 8 and $89 \mathrm{~kg}$ of PCB 180 northwards into the Arctic region, reflecting a higher LRT potential for PCB28 than for PCB180. As the third largest emitter of PCBs in the world (Table 1), Asian region was a net sink for PCBs with an annual PCB28 (PCB180) import of $20276 \mathrm{~kg}(213 \mathrm{~kg})$ and an export of $13112 \mathrm{~kg}(121 \mathrm{~kg})$. Relative to the total PCB28 (PCB180) imported into each region, the eastward transports of PCBs contributed about $100 \%$ (90\%) to Asian region from Europe, 99\% (95\%) to North Pacific region from Asia, 63\% (80\%) to North American region from North Pacific and $99 \%$ (97\%) to Atlantic region from North America. This further confirmed that the eastward LRT of PCBs is dominant in the mid-latitude of NH. Situated in the downwind of Asia and North America, North Pacific and Atlantic were also the major sinks for both PCB28 and PCB180 during their LRT. Corresponding with the ridges of westerly wave in the $\mathrm{NH}$, the meridional transports across the northern boundaries (Arctic Circle at $66.5^{\circ} \mathrm{N}$ ) were also important especially for Europe, 


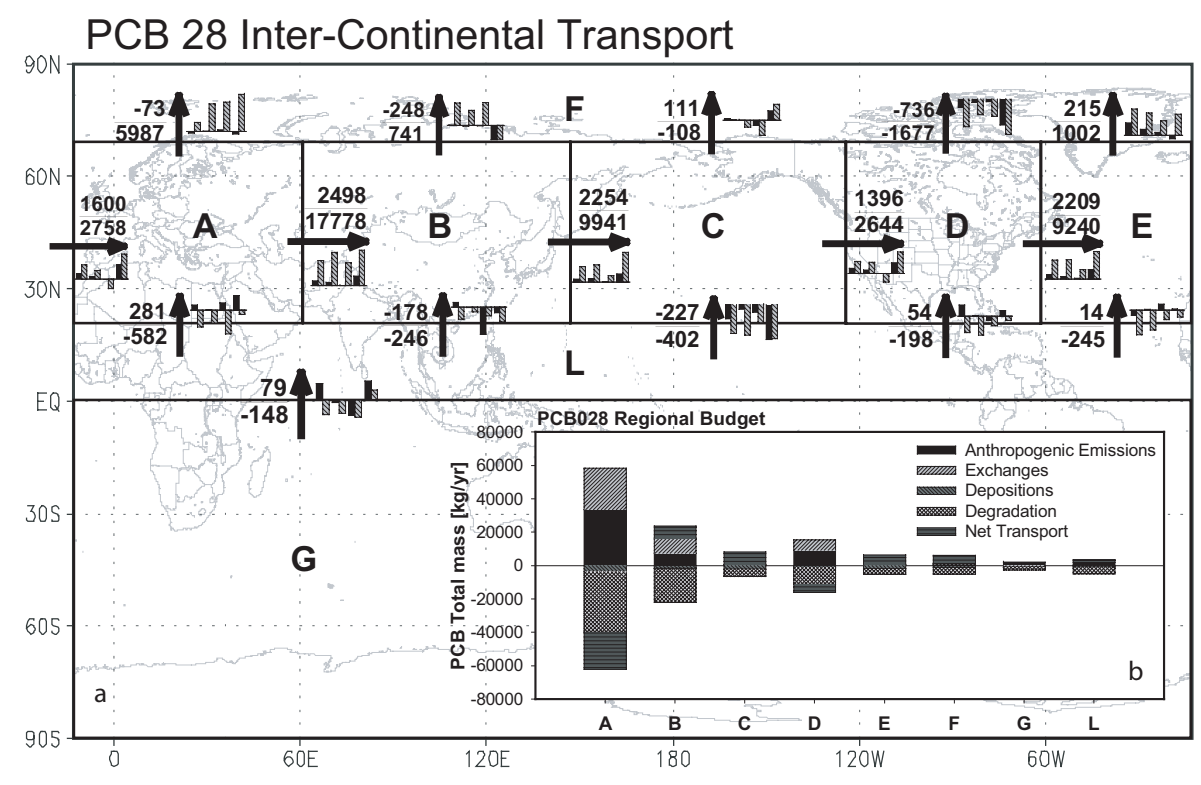

Fig. 3. (a) Inter-continental transports of PCB28. The transport masses at four sides of each region are marked with a pair of numbers (particulate/gaseous PCBs in $\mathrm{kg} \mathrm{yr}^{-1}$ ), an arrow and a bar chart. A positive or negative number indicates the same or opposite transport directions as the arrows. The bar charts beside each arrow show the PCB transport masses of PCB particles (black bars) and gas (gray bars) through region boundary in winter, spring, summer and fall. (b) (Inner figure) PCB28 regional budget $\left(\mathrm{kg} \mathrm{yr}^{-1}\right)$.

North America and Atlantic with the substantial exports and imports (Figs. 3a and 4a). These were the alternative pathways of inter-continental transports across Arctic besides the zonal transports. The transport fluxes of PCB28 and PCB180 in winter, spring, summer and fall were also shown in the bar charts of Figs. 3a and 4a. There existed seasonal variations of PCB-transports for each region but no general conclusions can be drawn.

\subsection{Transport to the Arctic}

Governed by the seasonal changes in westerly wave with trough and ridge in mid-and high-latitudes the pattern of PCB-transports into the arctic presented obvious seasonal variations. Corresponding with the seasonal position and strength of the westerly ridges, PCBs entered the Arctic circle northwards in winter/spring via the following three regions: 1) East Europe to central Asia, 2) western Pacific and 3) eastern Atlantic (Figs. 2a-b and 2e-f), and in summer via the following two regions: 1) from Europe to western Asia and 2) from eastern North America to western Atlantic (Figs. 2c-d and $2 \mathrm{~g}-\mathrm{h}$ ) as well as in autumn with four entrances: 1) from Eastern Atlantic to Western Europe, 2) over central Asia, 3) north Pacific and 4) from eastern North America to western Atlantic. Annually, the Arctic received $5914 \mathrm{~kg}$ ( $89 \mathrm{~kg}$ ) of PCB28 (PCB180) from European region, $1217 \mathrm{~kg}(26 \mathrm{~kg})$ from North Atlantic region and exported $2413 \mathrm{~kg}$ (8.7 kg) of PCB28 (PCB180) to North American region and $21.4 \mathrm{~kg}$ PCB180 to Asian region. The transports from Europe to Arctic and from North Atlantic (the source in North America) to the Arctic contributed the most PCBs. As a pure sink of global PCBs, the Arctic region received a net import of $5214 \mathrm{~kg}(80 \mathrm{~kg})$ of PCB28 (PCB180) (Figs. 3a and 4a). It was also found that not only more gaseous PCB28 transported from Europe into the Arctic than particulate PCB28 but also they crossed the Arctic Circle in opposite directions from the northern boundaries of Europe, Asia and North Pacific (Fig. 3a). This can be explained by the vertical meridional circulation structures that are responsible for the transports of gaseous PCB28 in middle troposphere and particulate PCB28 in upper troposphere. Compared to the eastward transports, PCB180 had strong meridional transport components to carry more PCBs from directly the sources in Europe and North America into Arctic than PCB28 (Figs. 2a-d, 3a and 4a), because PCB180-transports were limited in the lower atmospheric layers with the more impacts of surface.

\subsection{Transport between NH and SH}

In the NH, most of PCBs emitted in Europe, South/East Asia and North America (Table 1). PCBs originated from these regions transported between $\mathrm{NH}$ and $\mathrm{SH}$ across the equator in different flow-paths. For PCB28 (Figs. 2a-d) and PCB180 (Figs. 2e-h), there were three pathways of cross equatorial transports: 1) southwards from Europe into the easterly jet over tropical Africa and Atlantic for the whole year, 2) southwards from East and South Asia with winter monsoon to the SH and northwards with summer monsoon from the SH to South and East Asia and 3) from North America around the 


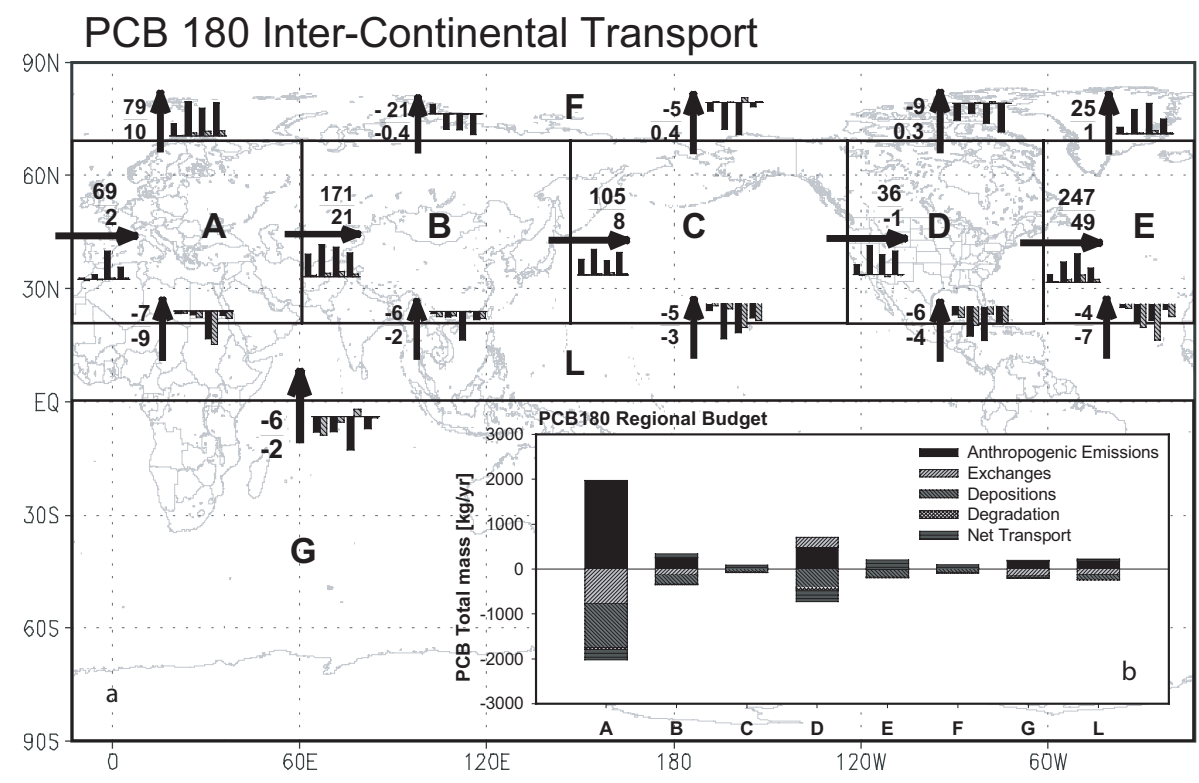

Fig. 4. Same as in Fig. 3, but for PCB180.

subtropical High into trade winds in the tropics. The transport directions of pathway 2 from South/East Asia to tropical Indian Ocean and west Pacific were seasonally shifted accompanying Asian summer and winter monsoon. It is interesting to notice that the summertime PCBs in the low and middle troposphere could transport from the $\mathrm{SH}$ to $\mathrm{NH}$ across the equator. Due to the most transports of PCB28 particles in the upper troposphere in the tropics (Fig. 1h), their cross equatorial transports presented the opposite directions with the gaseous PCB28's in the most tropical regions especially in winter and summer (Figs. 2a-d), corresponding to the meridional and zonal circulations between lower and upper troposphere in the tropics. The opposite directions of these cross equatorial transports for gaseous and particulate PCB28 are also seen from their annual total gaseous PCB28 of $148 \mathrm{~kg}$ from $\mathrm{NH}$ to $\mathrm{SH}$ and particulate PCB28 of $79 \mathrm{~kg}$ from SH to NH in 2000 (Fig. 3a). The seasonal shift of the cross equatorial transports between the $\mathrm{NH}$ and $\mathrm{SH}$ for both gaseous and particulate PCB28 were obviously demonstrated, especially between summer and winter (Figs. 2a, b and 3a), which implied that PCBs from the SH could enter and affect the $\mathrm{NH}$ under some favourable conditions. As the passages of the cross equatorial transports from the PCBsources in the northern mid-latitudes, the northern lower latitude region gained $1729 \mathrm{~kg}(53 \mathrm{~kg})$ from the mid-latitudes and exported $69 \mathrm{~kg}(8 \mathrm{~kg})$ of total PCB28 (PCB180) to the $\mathrm{SH}$. Both regions $\mathrm{L}$ and $\mathrm{G}$ were the receptor-regions of global PCB-transports (Figs. 3a and 4a).

\section{Global budgets of PCBs}

\subsection{Anthropogenic emissions}

According to Breivik et al. (2002) by a mass balance approach, the global annual emissions of the three PCB congeners of 28,153 and 180 simulated in this study are 54663 , 12099 and $3104 \mathrm{~kg}$, respectively. Redistributed in each country by its population distribution, the global $1^{\circ} \times 1^{\circ}$ grid emissions were produced. Table 1 shows the regional contribution of three PCBs to the total global emissions. It is obvious that industrialized regions of the $\mathrm{NH}$ contribute majority of the anthropogenic PCBs with about $64 \%$ contributions from Europe, $15 \%$ from North America and 10\% from Asia. It should be noted that only the high emission scenario of the three estimates provided in Breivik et al. (2002) was employed in this study.

\subsection{Soil and water fluxes to the atmosphere}

The soil and water fluxes emitted to the atmosphere were estimated by two exchange modules in GEM/POPs (Gong et al., 2007) based on the soil and water concentrations of the three PCBs in this study. Because of the uncertainties associated with the estimates of soil and water concentrations, these values are also subject to large uncertainties. However, given the fact that these soil and water PCB concentrations used in our previous studies have yielded reasonable atmospheric PCB concentrations compared with observations, estimates of the fluxes with these soil and water concentrations could give an order of magnitude approximation. Table 1 shows the three categories of emissions for PCB28, 153 and 180: 

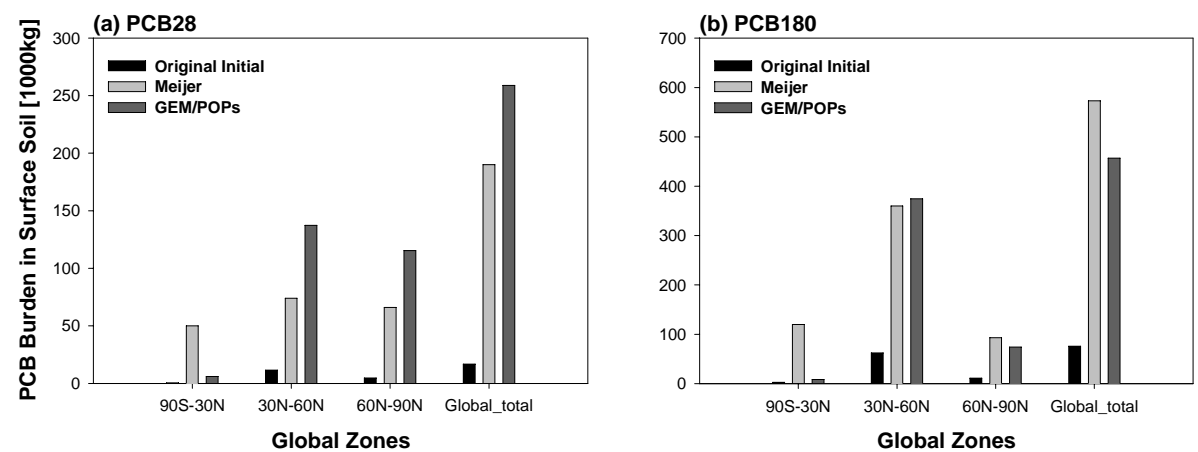

Fig. 5. Soil PCB burden in global zones $\left(90^{\circ} \mathrm{S}-30^{\circ} \mathrm{N}, 30^{\circ} \mathrm{N}-60^{\circ} \mathrm{N}\right.$ and $\left.60^{\circ} \mathrm{N}-90^{\circ} \mathrm{N}\right)$ and global total, (a) for PCB28 and (b) for PCB 180 .

anthropogenic, soil and water. A positive value in the table indicates an upward flux to the atmosphere and vice versa.

The estimated fluxes of three PCBs from soil and water for the $\mathrm{SH}$ are all negative, indicating that the entire southern eco-system is still a net sink for global PCBs. This is also true for all the water and soil compartments in the lower latitude region. In other regions, the directions of PCB exchanges depend on the regional soil and water concentrations and PCB congeners. The sign of the exchange fluxes between soil/water and atmosphere is determined by the relative magnitudes of the fugacity for a chemical concerned in each media (Mackay, 2001). Simulated results show that fugacity of PCB28 in most northern soil and water compartments is larger than that in the atmosphere, which results in a net flux of PCB28 from soil and water to the atmosphere. The sum of soil and water emission fluxes to the atmosphere for PCB28 had reached or surpassed the same magnitude as the anthropogenic emissions. The ratio of soil and water to anthropogenic fluxes of PCB28 for year 2000 was 0.74 in Europe, 1.27 in Asia, 0.67 in North America and 2.57 in the Arctic. This indicates that PCB28 in soil and water has become a net source for PCBs after years of depositions from the past usage as suggested by the previous studies (Harrad et al., 1994; Hung et al., 2005a; Jaward et al., 2004). For most regions, anthropogenic emissions are still the dominant source of heavier PCBs (PCB153 and 180) while soil and water compartments continue receiving PCBs from the atmosphere and building up their burden except for soil in North America (Jaward et al., 2004) and the Arctic for PCB180 (Table 1) (Harrad et al., 1994).

Initial soil concentrations play a very important role in the atmospheric concentrations of PCBs. When the original initial soil concentrations of selected PCB congeners from the MSC-East model were used, the global air concentrations of PCBs produced by the GEM/POPs were too low to compare with observations. The MSC-East global soil burden of PCBs was $16819 \mathrm{~kg}$ for PCB28 and $75857 \mathrm{~kg}$ for PCB180 (Figs. 5a and b), which was about one order of magnitude less than the previous study (Meijer et al., 2003). After a 3DVAR data assimilation scheme was applied to the ini- tial soil concentrations by using the observational data from Meijer et al. (2003), the air concentrations of PCBs were improved greatly and comparable with observations (Gong et al., 2007). GEM/POPs estimated the zonal surface soil burden of PCB180 as $374594 \mathrm{~kg}$ between $30^{\circ} \mathrm{N}-60^{\circ} \mathrm{N}$ and $73924 \mathrm{~kg}$ between $60^{\circ} \mathrm{N}-90^{\circ} \mathrm{N}$ (Fig. 5b), agreeing reasonably well with the estimates by Meijer et al. (2003). Surface soil burden of PCB28 was overestimated $36 \%$, but its distribution in the two zonal regions, $30^{\circ} \mathrm{N}-60^{\circ} \mathrm{N}$ and $60^{\circ} \mathrm{N}-$ $90^{\circ} \mathrm{N}$, matched the results of Meijer et al. (2003) very well (Fig. 5a). Due to the lack of observational soil data set in the zonal area between $90^{\circ} \mathrm{S}-30^{\circ} \mathrm{N}$, no substantial improvements were made (Fig. 5a and b).

The global soil burden of PCB28 from GEM/POPs was about $258776 \mathrm{~kg}$ and the annual cumulative emission from soil was $40625 \mathrm{~kg}$. About $16 \%$ of soil burden of PCB28 revolatilized to the atmosphere, which is almost close to the magnitude of anthropogenic emission of PCB28 in year 2000 (Table 1). Other modeling studies (e.g. Malanichev et al., 2004) have also discussed about the relative importance of reemission vs. primary emissions of PCBs. This modeling result indicates that the emission of lighter PCBs (e.g. PCB28) are more probable to be dominated by re-emissions rather than primary emissions. For heaver congeners, PCB153 and PCB 180, although their global soil burden calculated by GEM/POPs were $573165 \mathrm{~kg}$ and $456913 \mathrm{~kg}$, their net soilatmosphere exchange in the year 2000 were $6481 \mathrm{~kg}$ and $871 \mathrm{~kg}$ toward to the soil compartment, respectively. This is consistent with a study by Hung et al. (2005) who concluded that the primary emissions of heaver congeners (e.g. PCB153 and PCB180) were still the dominant source to the atmosphere in year 2000 .

\subsection{Source and receptor regions of global PCBs}

In addition to the inter-continental transport fluxes, Figs. 4b and $5 \mathrm{~b}$ also show the budget information of PCB28 and 180 for each region to investigate the mass transfers due to anthropogenic emissions and air-surface exchange processes, and the removal processes. For the convenience of 
Table 2. Regional PCB Budgets Estimated by GEM/POPs.

\begin{tabular}{|c|c|c|c|c|c|c|c|c|c|c|c|c|c|c|c|}
\hline \multirow[t]{2}{*}{ Region } & \multicolumn{5}{|c|}{ PCB28 } & \multicolumn{5}{|c|}{ PCB 153} & \multicolumn{5}{|c|}{ PCB180 } \\
\hline & $\begin{array}{c}E_{\mathrm{ms}} \\
{[\mathrm{kg} / \mathrm{yr}]}\end{array}$ & $\begin{array}{c}E_{\mathrm{ms}} \\
\%\end{array}$ & $\begin{array}{c}L_{\text {depo }} \\
\%\end{array}$ & $\begin{array}{c}L_{\text {decay }} \\
\%\end{array}$ & $\begin{array}{c}T_{\text {rans }} \\
\%\end{array}$ & $\begin{array}{c}E_{\mathrm{ms}} \\
{[\mathrm{kg} / \mathrm{yr}]}\end{array}$ & $\begin{array}{c}E_{\mathrm{ms}} \\
\%\end{array}$ & $\begin{array}{c}L_{\text {depo }} \\
\%\end{array}$ & $\begin{array}{c}L_{\text {decay }} \\
\%\end{array}$ & $\begin{array}{c}T_{\mathrm{rans}} \\
\%\end{array}$ & $\begin{array}{c}E_{\mathrm{ms}} \\
{[\mathrm{kg} / \mathrm{yr}]}\end{array}$ & $\begin{array}{c}E_{\mathrm{ms}} \\
\%\end{array}$ & $\begin{array}{c}L_{\text {depo }} \\
\%\end{array}$ & $\begin{array}{c}L_{\text {decay }} \\
\%\end{array}$ & $\begin{array}{c}T_{\text {rans }} \\
\%\end{array}$ \\
\hline A & 58408.20 & 60.56 & 3.92 & 37.51 & -22.95 & 7974.51 & 65.91 & 55.18 & 3.75 & -7.24 & 1974.27 & 59.28 & 52.48 & 1.36 & -6.79 \\
\hline B & 16528.77 & 17.14 & 1.77 & 21.21 & 7.43 & 1178.72 & 9.74 & 10.85 & 0.83 & 2.50 & 251.83 & 7.56 & 10.04 & 0.25 & 2.71 \\
\hline $\mathrm{C}$ & 587.32 & 0.61 & 2.37 & 4.57 & 7.80 & 36.19 & 0.30 & 1.57 & 0.14 & 1.65 & 9.76 & 0.29 & 2.18 & 0.06 & 2.23 \\
\hline $\mathrm{D}$ & 15449.87 & 16.02 & 1.06 & 10.46 & -5.33 & 1488.72 & 12.30 & 8.67 & 1.22 & -2.79 & 703.86 & 21.13 & 12.50 & 1.34 & -7.90 \\
\hline $\mathrm{E}$ & 623.75 & 0.65 & 1.89 & 3.65 & 5.85 & 37.83 & 0.31 & 2.85 & 0.32 & 2.79 & 10.57 & 0.32 & 5.58 & 0.21 & 5.68 \\
\hline $\mathrm{F}$ & 927.22 & 0.96 & 1.28 & 4.20 & 5.41 & 37.28 & 0.31 & 1.68 & 0.06 & 1.72 & 11.59 & 0.35 & 2.52 & 0.02 & 2.46 \\
\hline $\mathrm{G}$ & 1985.06 & 2.06 & 1.09 & 1.84 & 0.07 & 683.97 & 5.65 & 5.58 & 0.33 & 0.31 & 187.50 & 5.63 & 5.93 & 0.09 & 0.24 \\
\hline $\mathrm{L}$ & 1942.38 & 2.01 & 0.82 & 4.22 & 1.72 & 662.75 & 5.48 & 5.72 & 0.87 & 1.07 & 181.08 & 5.44 & 6.79 & 0.29 & 1.37 \\
\hline
\end{tabular}

the analysis, the total global emission (TGE) for PCB28, PCB153 and PCB180 is defined as the sum of its anthropogenic emissions plus the upward fluxes from water/soil to the atmosphere for year 2000 with its regional counterpart as $E_{\mathrm{ms}}(\mathrm{kg} / \mathrm{yr})$. The regional removal of each congener consists of two contributions: gas-phase reactions with $\mathrm{OH}$ ( $L_{\text {decay }}, \mathrm{kg} / \mathrm{yr}$ ) and dry and wet removal processes of gases and particles in atmosphere $\left(L_{\text {depo }}, \mathrm{kg} / \mathrm{yr}\right) . T_{\text {rans }}(\mathrm{kg} / \mathrm{yr})$ is the net mass transported through the boundaries of each region with a positive value as a net import into the region and vice versa. Table 2 presents the $E_{\mathrm{ms}}$, percentage of $L_{\text {depo }}, L_{\text {decay }}$ and $T_{\text {rans }}$ of three PCBs over each region with respect to the TGE.

$T_{\text {rans }} \%$ for regions A and D were negative for all three congeners (Table 2), indicating that they were source regions and exported all three PCBs in year 2000 to other regions where $T_{\text {rans }} \%$ were positive. According to the modeling results, TGE was $96453 \mathrm{~kg}, 12100 \mathrm{~kg}$ and $3330 \mathrm{~kg}$ for PCB28, PCB153 and PCB180, respectively, among which Europe and North America together contributed $73858 \mathrm{~kg}, 9463 \mathrm{~kg}$ and $2678 \mathrm{~kg}$. $T_{\text {rans }} \%$ for PCB28, PCB153 and PCB180 over the two regions were $-28 \%,-10 \%$ and $-15 \%$ of TGE, which are translated into a net export of $27277 \mathrm{~kg}, 1214 \mathrm{~kg}$ and $489 \mathrm{~kg}$ of PCB28, PCB153 and PCB180 to other regions (Table 2, Figs. 3b, 4b). It should be noted that Asia, the third biggest contributor of PCBs into the atmosphere, was a receptor as its $T_{\text {rans }} \%>0$ for all three congeners. Total $T_{\text {rans }} \%$ over Asia, Pacific, Atlantic and Arctic for PCB28, PCB153 and PCB 180 are $26 \%, 9 \%$ and $13 \%$ of TGE, respectively (Table 2). This indicates that the four regions are the primary receptors of PCBs in the globe. Whereas regions $\mathrm{G}$ and $\mathrm{L}$ have considerable large area, but as receptors, they only receive very small amount of masses from other regions (Table 2) and therefore slightly affected by the northern source regions.

\subsection{Removals and vertical distributions of different PCB congeners}

According to Table 2, 68\%, $89 \%$ and $91 \%$ of PCB28, PCB153 and PCB180 emitted from European region were removed in the area. For PCB28, 91\% of the removal was due to the reaction with $\mathrm{OH}$ in the atmosphere and only $9 \%$ was due to depositions. However, for heavier congeners of PCB153 (PCB180), 94\% (97\%) removals in region A were due to wet and dry depositions with the remaining percentages by gaseous PCB reactions with $\mathrm{OH}$ in the atmosphere. This phenomenon existed in all regions as well (Table 2 and Figs. 3b, 4b). On the global scale, the removal of PCB28 by reaction with $\mathrm{OH}$ radicals was much larger than the sum of loss of PCB153 and PCB180 by OH reaction (Table 2). Those quantitative results calculated by GEM/POPs' are in agreement with the findings presented in previous studies (Wania and Daly, 2002).

The dynamic processes of emissions, transport and deposition determine the atmospheric loading of PCBs. Consequently, an accurate dry and wet deposition velocity and flux is needed to realistically predict the budgets of PCBs. Compared to other studies (e.g. Jurado et al., 2004), GEM/POPs captured the general pictures of global PCB depositions. For example, it is noticeable that Atlantic region was a receptor and the deposition was an important process for the heavier PCB congeners in that region. Relative high dry deposition flux was found around $30^{\circ} \mathrm{N}$ to $86^{\circ} \mathrm{N}$ in the Atlantic area and the highest value was $500 \mathrm{pg} / \mathrm{m}^{2} /$ day at $53^{\circ} \mathrm{N}$. This distribution was associated with the high air concentration in that area and consistent with the distribution and magnitude estimated by Jurado et al. (2004). Wet deposition flux of PCB180 also presented a correlation to its air concentration: a peak value was predicted from $30^{\circ} \mathrm{N}$ to $86^{\circ} \mathrm{N}$. Particle scavenging dominated the wet removal process (Jurado et al., 2005), which agrees with the prediction by GEM/POPs that 92\% of the total deposition flux for PCB180 in the meridional region of Atlantic Ocean between $1^{\circ} \mathrm{E}-20^{\circ} \mathrm{E}$ was due to wet scavenging. 
Table 3. The vertical distributions of global PCB burdens averaged in year 2000 with the fractions of PCBs accumulated at the certain levels in the whole column loading in the atmosphere.

\begin{tabular}{lcccccc}
\hline $\begin{array}{l}\text { Level } \\
\text { Height }\end{array}$ & $\begin{array}{c}\text { Gaseous } \\
\text { PCB28 }\end{array}$ & $\begin{array}{c}\text { Particulate } \\
\text { PCB28 }\end{array}$ & $\begin{array}{c}\text { Gaseous } \\
\text { PCB153 }\end{array}$ & $\begin{array}{r}\text { Particulate } \\
\text { PCB153 }\end{array}$ & $\begin{array}{c}\text { Gaseous } \\
\text { PCB180 }\end{array}$ & $\begin{array}{c}\text { Particulate } \\
\text { PCB180 }\end{array}$ \\
\hline$>15 \mathrm{~km}$ & 0.1589 & 0.5473 & 0.0000 & 0.0029 & 0.0000 & 0.0014 \\
$6-15 \mathrm{~km}$ & 0.1127 & 0.3724 & 0.0161 & 0.2364 & 0.0055 & 0.1681 \\
$1-6 \mathrm{~km}$ & 0.4816 & 0.0698 & 0.5840 & 0.5630 & 0.5500 & 0.5760 \\
$<1 \mathrm{~km}$ & 0.2468 & 0.0105 & 0.3999 & 0.1976 & 0.4446 & 0.2545 \\
\hline
\end{tabular}

PCBs' removal pattern over Pacific and Atlantic areas greatly depends on the different LRT potential of PCBs. The area of the Atlantic Ocean is almost half as that of the Pacific, but the removals of PCB180 in Atlantic were twice as those in Pacific (Table 2, Figs. 3b, 4b). Yet for PCB28, the removals were proportional to area of the two regions (Figs. 3b, $4 b)$. This once again demonstrates the difference of LRT potential of various PCBs with lighter congeners more uniformly distributed around globe and heavier congeners limited close to their source regions.

The differential removals of various PCBs also influence their burdens in the atmosphere. Averaged over year 2000, the global PCB-burdens in the whole model levels from surface to the model top about $30 \mathrm{~km}$ are estimated with 1852 (354) kg, 45 (37) kg and 10 (24) kg for gaseous (particulate) PCB28, PCB153 and PCB180, respectively. Contributed from the different emissions of the three PCB congeners (Table 1), much more PCB28 than PCB153 and PCB180 were loaded in the atmosphere, where more gas than particle for lighter PCB28 and more particles than gas for heavier PCB180 remained.

Table 3 quantified the fractions of PCB burdens accumulated within boundary layer below $1 \mathrm{~km}$, in the lower (1-6 km), upper $(6-15 \mathrm{~km})$ troposphere and the stratosphere over $15 \mathrm{~km}$ to the total loading in the whole model column. The vertical distributions of the three PCB congeners in gas and particle in the atmosphere were presented in Table 3 . For all three congeners, particulate PCBs concentrated in the higher levels than gaseous PCBs due to the more particle condensation in the cold air at higher levels. More than half of the particulate PCB28 could reach up to the stratosphere, while the heavier congeners (PCB153 and PCB180) are mostly stored in the troposphere including the boundary layer. For gaseous PCB180, more than 99\% were below $6 \mathrm{~km}$ in the lower levels.

\section{Conclusions}

The budgets and deposition patterns of inter-continental transports of three PCBs were investigated with the 3-D global POPs transport model - GEM/POPs in this study. The PCBs mostly transported eastwards with westerlies below about $4 \mathrm{~km}$ for the gaseous PCB180, $6 \mathrm{~km}$ for the particulate PCB180, $8 \mathrm{~km}$ for the gaseous PCB28 and $14 \mathrm{~km}$ for particulate PCB28 with the maximal transport centers around $50^{\circ} \mathrm{N}$ averaged in year 2000. The major transport layers of particulate PCB28 descended from the low-, mid- and high latitudes in the both hemispheres. The PCBs from the regions of $40-50^{\circ} \mathrm{N}$ could transport northwards into the arctic region and southwards into the low-latitudes, and even cross equator into the Southern Hemisphere. Modeled results demonstrate that most emitted PCBs become deposited near their source areas and also imply that atmospheric degradation is more important for the lighter congeners of PCBs, whereas dry and wet depositions appear the dominant removal process in atmosphere for heavier PCBs over both source and remote regions.

The inter-continental transports of PCBs in the Northern Hemisphere are dominant in the zonal direction with their route changes governed by the seasonal variation of westerly jet. The seasonally averaged PCBs from the mid-latitudes northwards flowed into the Arctic Circle with three, two and four entrances in spring/winter, summer and autumn, respectively. The transports from Europe and North America via North Atlantic Ocean contributed the most PCBs to the Arctic. PCBs from three major contributing regions could also be transported across the equator in three different flow-paths, accompanying with easterly jet, Asian monsoon winds, subtropical high and trade winds. PCBs from the Southern Hemisphere could export into the Northern Hemisphere.

It is found that a net flux of PCB 28 from soil and water to the atmosphere exists for 2000. For heavier PCBs the net fluxes are in the reverse direction from atmosphere to the soil and water. Two PCB source regions of Europe and North America, contribute PCB28, PCB153 and PCB180 loading to atmosphere at $77 \%, 78 \%$ and $80 \%$ of the global gross emission mass in year 2000. Asia, Pacific, Atlantic and Arctic region are identified as the major global net sinks and have total net mass inflows of the three PCBs at $25550 \mathrm{~kg} / \mathrm{yr}$, $1048 \mathrm{~kg} / \mathrm{yr}$ and $436 \mathrm{~kg} / \mathrm{yr}$ (PCB28, PCB153 and PCB180) from other source regions.

This study is a first attempt with a 3-D global POPs transport model to study the budgets and inter-continental 
transports of various PCBs. The results have shown that GEM/POPs could properly address behaviors of PCBs in atmosphere. More processes of PCBs in environment and longer simulations of PCBs are recommended to study historical global fate of PCBs in the future.

Acknowledgements. The authors wish to thank CFCAS (The Canadian Foundation for Climate and Atmospheric Sciences) for its partial finical support for this research through the NW AQ MAQNet Grant.

Edited by: A. Stohl

\section{References}

Breivik, K., Sweetman, A., Pacyna, J. M., and Jones, K. C.: Towards a global historical emission inventory for selected PCB congeners - a mass balance approach 2. Emissions, Sci. Total Environ., 290, 199-224, 2002.

Côté, J., Gravel, S., Méthot, A., Patoine, A., Roch, M., and Staniforth, A.: The operational CMC-MRB Global Environmental Multiscale (GEM) model: Part I - Design considerations and formulation, Mon. Wea. Rev., 126, 1373-1395, 1998.

Gong, S. L., Barrie, L. A., Blanchet, J.-P., Salzen, K. v., Lohmann, U., Lesins, G., Spacek, L., Zhang, L. M., Girard, E., Lin, H., Leaitch, R., Leighton, H., Chylek, P., and Huang, P.: Canadian Aerosol Module: A size-segregated simulation of atmospheric aerosol processes for climate and air quality models 1. Module development, J. Geophys. Res., 108, 4007, doi:10.1029/2001JD002002, 2003.

Gong, S. L., Huang, P., Zhao, T. L., Sahsuvar, L., Barrie, L. A., Kaminski, J. W., Li, Y. F., and Niu, T.: GEM/POPs: A Global 3-D Dynamic Model for Semi-volatile Persistent Organic Pollutants - Part 1: Model description and evaluations, Atmos. Chem. Phys., 7, 4001-4013, 2007, http://www.atmos-chem-phys.net/7/4001/2007/.

Hansen, K. M., Christensen, J. H., Brandt, J., Frohn, L. M., and Geels, C.: Modelling atmospheric transport persistent organic pollutants in Northern Hemisphere with a 3-D dynamical model: DEHM-POP, Atmos. Chem. Phys., 4, 1339-1369, 2005, http://www.atmos-chem-phys.net/4/1339/2005/.

Harrad, S. J., Sewart, A. P., Alcock, R., Boumphrey, R., Burnett, V., Duarte-Davidson, R., Halsall, C., Sanders, G., Waterhouse, K., Wild, S. R., and Jones, K.: Polychlorinated Biphenyls (PCBs) in the British Environment: Sinks, Sources and Temporal Trends, Environ. Pollut., 85, 131-146, 1994.

Hung, H., Blanchard, P., Halsall, C. J., Bidleman, T. F., Stern, G. A., Fellin, P., Muir, D. C. G., Barrie, L. A., Jantunen, L. M., Helm, P. A., Ma, J., and Konoplev, A.: Temporal and spatial variabilities of atmospheric polychlorinated biphenyls (PCBs), organochlorine (OC) pesticides and polycyclic aromatic hydrocarbons (PAHs) in the Canadian Arctic: Results from a decade of monitoring, Sci. Total Environ., 342, 119-144, 2005a.

Hung, H., Lee, S. C., Wania, F., Blanchard, P., and Brice, K.: Measuring and simulating atmospheric concentration trends of polychlorinated biphenyls in the Northern Hemisphere, Atmos. Environ., 39, 6502-6512, 2005b.
Jaward, F. M., Barber, J. L., Booij, K., Dachs, J., Lohmann, R., and Jones, K. C.: Evidence for dynamic air-water coupling and cycling of persistent organic pollutants over the open Atlantic Ocean, Environ. Sci. Technol., 38, 2617-2625, 2004.

Jurado, E., Jaward, F., Lohmarm, R., Jones, K. C., Simo, R., and Dachs, J.: Wet deposition of persistent organic pollutants to the global oceans, Environ. Sci. Technol., 39, 2426-2435, 2005.

Jurado, E., Jaward, F. M., Lohmann, R., Jones, K. C., Simo, R., and Dachs, J.: Atmospheric dry deposition of persistent organic pollutants to the Atlantic and inferences for the global oceans, Environ. Sci. Technol., 38, 5505-5513, 2004.

Koziol, A. S. and Pudykiewicz, J. A.: Global-scale environmental transport of persistent organic pollutants, Chemosphere, 45, 1181-1200, 2001.

Ma, J., Daggupaty, S., Harner, T., and Li, Y.-F.: Impacts of Lindane usage in the Canadian prairies on the Great Lakes ecosystem, 1. Coupled atmospheric transport model and modeled concentrations in air and soil, Environ. Sci. Technol., 37(17), 3774-3781, 2003.

Mackay, D.: Multimedia Environmental Models: The Fugacity Approach, CRC Press, New York, 2001.

Mackay, D., Webster, E., and Gouin, T.: Partitioning, Persistence and Long-Range Transport, in: Chemicals in the Environment: Assessing and Managing Risk, edited by: Hester, R. E. and Harrison, R. M., Royal Society of Chemistry, Cambridge, UK, 2006.

MacLeod, M., Riley, W. J., and McKone, T.: Assessing the Influence of Climate Variability on Atmospheric Concentrations of Polychlorinated Biphenyls Using a Global-Scale Mass Balance Model (BETR-Global), Environ. Sci. Technol., 39, 6749-6756, 2005.

Malanichev, A., Mantseva, E., Shatalov, V., Strukov, B., and Vulykh, N.: Numerical evaluation of the PCBs transport over the Northern Hemisphere, Environ. Pollut., 128, 279-289, 2004.

Semeena, V. S. and Lammel, G.: The significance of the grasshopper effect on the atmospheric distribution of president organic substances, Geophys. Res. Lett., 32, L07804, doi:10.1029/2004GL022229, 2005.

Strand, A. and Hov, Ø.: A model strategy for the simulation of chlorinated hydrocarbon distributions in the global environment, Water Air Soil Poll., 86, 283-316, 1996.

van Jaarsveld, J. A., van Pul, W. A. J., and de Leeuw, F. A. A. M.: Modelling transport and deposition of persistent organic pollutants in the European region, Atmos. Environ., 31, 1011-1024, 1997.

Wania, F.: Assessing the potential of persistent organic chemicals for long-range transport and accumulation in polar regions, Environ. Sci. Technol., 37, 1344-1351, 2003.

Wania, F. and Daly, G. L.: Estimating the contribution of degradation in air and deposition to the deep sea to the global loss of PCBs, Atmos. Environ., 36, 5581-5593, 2002.

Wania, F., Mackay, D., Li, Y.-F., Bidleman, T. F., and Strand, A.: Global chemical fate of alpha-hexachlorocyclohexane. 1. Evaluation of a global distribution model, Environ. Toxicol. Chem., 18, 1390-1399, 1999.

Wania, F. and Su, Y.: Quantifying the Global Fractionation of Polychlorinated Biphenyls, Ambio, 33, 161-168, 2004. 